\title{
Microbial dynamics in autotrophic and heterotrophic seawater mesocosms. III. Organic matter fluxes
}

\author{
Hans-Peter Grossart ${ }^{1, *}$, Anja Engel ${ }^{2}$, Carol Arnosti ${ }^{3}$, Christina L. De La Rocha ${ }^{2}$, \\ Alison E. Murray ${ }^{4}$, Uta Passow ${ }^{2}$ \\ ${ }^{1}$ Institute of Freshwater Ecology and Inland Fisheries, Dept. of Limnology of Stratified Lakes, Alte Fischerhütte 2, \\ 16775 Stechlin, Germany \\ ${ }^{2}$ Alfred-Wegner-Institut für Polar- und Meeresforschung, Am Handelshafen 12, 27570 Bremerhaven, Germany \\ ${ }^{3}$ Department of Marine Sciences, University of North Carolina, Chapel Hill, North Carolina 27599-3300, USA \\ ${ }^{4}$ Division of Earth and Ecosystem Science, Desert Research Institute, 2215 Raggio Parkway, Reno, Nevada 89512, USA
}

\begin{abstract}
We monitored the dynamics of extracellular organic matter in 3 mesocosms: one dominated by a heterotrophic (microbial) community with negligible autotrophic activity (net heterotrophic system), a second where a small Phaeocystis bloom developed (production and loss almost balanced), and a third harboring a large diatom bloom (net autotrophic system). In all mesocosms, meso- and macroscopic heterotrophic organisms were excluded to primarily study extracellular organic matter production and turnover by specific algae and microbial loop organisms, respectively. Concentration and composition of dissolved organic matter (DOM), i.e. dissolved organic carbon (DOC), monosaccharides and total carbohydrates ( $\mathrm{MCHO}$ and $\mathrm{TCHO}$ ), free and combined neutral carbohydrates (DFCHO and DCCHO), as well as free and combined amino acids (DFAA and DCAA) were measured. In addition, net and gross community production rates were determined to calculate C-budgets. Whereas concentrations and composition of MCHO differed very little among the 3 mesocosms, dynamics of TCHO, DFCHO, and DCCHO differed significantly. Concentrations of DFAA were higher in both algal mesocosms compared to the heterotrophic system, and composition of DFAA was significantly different in the Phaeocystis and Diatom tanks. The composition and concentration of DCAA, however, were similar in all 3 mesocosms. Total dissolved carbohydrates and amino acids comprised a substantial fraction of the DOC pool. Dynamics of these DOC fractions, however, could only partly explain those of DOC, implying either that other dissolved compounds were important for overall C-cycling, or that microbial degradation of DOM affects the detection of carbohydrates and protein components.
\end{abstract}

KEY WORDS: Mesocosms · Organic carbon ' Amino acids ' Carbohydrates · Enzymes · Carbon budgets

\section{INTRODUCTION}

The majority of organic molecules occurring in the surface ocean are of algal origin (Meon \& Kirchmann 2001). Phytoplankton blooms substantially contribute to the release of dissolved organic carbon (DOC) in seawater (Myklestad 1995). However, the rate of release of photosynthetically fixed carbon is highly variable, ranging be- tween 1 and $70 \%$ (Baines \& Pace 1991). This extreme variability may point to methodological problems, such as enzymatic hydrolysis, the uptake of exudates by heterotrophic bacteria, or the disruption of cells during filtration. Nevertheless, large fluctuations in primary production and algal biomass during the development of algal blooms do cause distinct changes in amount and quality of aquatic dissolved organic matter (DOM). 
Generally, carbohydrates account for 20 to $30 \%$ of the DOC pool in oceanic surface waters (Benner et al. 1992, Pakulski \& Benner 1994), with polysaccharides quantitatively dominating its phytoplankton-produced portion (Lancelot \& Billen 1985). Simple carbohydrates and amino acids comprise a lesser portion of the DOC because they are either produced in lesser quantities or rapidly consumed by bacteria (Lancelot \& Billen 1985). Polysaccharides, however, can contribute up to $80 \%$ of the total extracellular release of the marine diatom Chaetoceros affinis in batch culture (Myklestad et al. 1989). This is in accordance with results from several mesocosms (Søndergaard et al. 2000) and field studies in the North Sea (Lancelot 1984), with diatoms and Phaeocystis sp. being the most dominant algal members.

Instances of massive production of extracellular polysaccharides are known from various marine environments and are often favored by nutrient depletion, as the synthesis and exudation of polysaccharides increase under these conditions (e.g. Obernosterer \& Herndl 1995, Biddanda \& Benner 1997, Søndergaard et al. 2000, Engel et al. 2004). However, high polysaccharide exudation has been also observed in nutrientenriched coastal regions, such as the southern North Sea and the English Channel, where Phaeocystis blooms frequently occur. Quantity and quality of the exuded organic matter is often characteristic for the algae releasing it (Myklestad 1974). Polysaccharidic mucilage comprises between 55 and $90 \%$ of the Phaeocystis carbon and is readily exuded (Lancelot 1995). Marine diatoms such as Skeletonema costatum typically exude high amounts of DOM, which is rich in carbohydrates, whereas coccolithophores such as Emiliana huxleyi release DOM with a lower portion of carbohydrates (Biersmith \& Benner 1998). Hence, concentration and composition of dissolved polysaccharides, as well as proteins exuded, vary with the development of different phytoplankton blooms.

Despite the high variability in composition of algalderived organic matter, a major fraction of the highmolecular-weight DOM recovered by ultrafiltration or dialysis shows a similar chemical composition with a relatively constant carbohydrate/acetate/lipid carbon ratio (Aluwihare et al. 1997, Borch \& Kirchman 1999). This finding indicates the rather recalcitrant nature of that DOC fraction which seems to resist rapid remineralization. When DOC accumulates over the growing season in the photic zone (e.g. Børsheim \& Myklestad 1997, Carlson et al. 1998, Williams 1998) production must outpace decomposition. The usual explanation for DOC accumulation is that the newly produced DOC is partly resistant to degradation and becomes more recalcitrant over time due to biotic and/or abiotic transformations (Søndergaard et al. 2000). Observa- tions of accumulation of biodegradable DOC, however, suggest that the breakdown and assimilation of carbon-rich DOM can also be limited by the availability of nitrogen (Williams 1995). In addition, trophic interactions, especially in the microbial food web, could keep the capacity for bacterial DOC decomposition low when specific environmental conditions, e.g. depletion of inorganic nutrients, prevail (Thingstad \& Lignell 1997, Thingstad et al. 1997).

In the present study, we used mesocosms to follow concentration and composition of DOM during 3 distinctly different algal growing conditions. Since we set our focus primarily on microbial processes, we excluded meso- and macroscopic heterotrophic organisms by pre-filtration. The main objective of our study was to test whether C-partitioning and cycling of extracellular organic matter are different in net autotrophic versus net heterotrophic systems and for different phytoplankton communities. We further sought to determine whether these differences are reflected in the amount and composition of the major DOM fractions (dissolved amino acids and carbohydrates).

\section{MATERIALS AND METHODS}

Mesocosms and sampling. Three $1000 \mathrm{l}$ mesocosms were filled with North Sea water that was sampled ca. $1 \mathrm{~km}$ off Helgoland island, Germany, at $2 \mathrm{~m}$ depth on 15 March 2002 and was stored in the dark at $4^{\circ} \mathrm{C}$ until the mesocosms were simultaneously filled on 17 March. Half of the water was filtered through $50 \mathrm{kDa}$ cartridges and the rest through a $1.2 \mu \mathrm{m}$ cartridge. Storage and pre-filtration reduced the amount of labile DOM, particulate organic matter (POM), and bacteria and fully excluded meso- and macroscopic heterotrophic organisms. All mesocosms were mixed overnight prior to inoculation with phytoplankton. No phytoplankton was added to the No Addition tank. The Phaeocystis tank was inoculated with $1.5 \mathrm{l}$ of a nonaxenic culture of $P$. globosa, and the Diatom tank with 31 each of axenic Chaetoceros decipiens and Thalassiosira pseudonana cultures. The Diatom tank was also supplemented with an additional $15 \mu \mathrm{mol} \mathrm{l}^{-1}$ silicic acid to stimulate diatom growth. The addition of phytoplankton slightly increased the concentration of inorganic nutrients, e.g. at $0.7 \mathrm{~d}$ after algal addition the concentration of phosphate was $0.8 \mu \mathrm{M}$ in the No Addition tank, $0.9 \mu \mathrm{M}$ in the Phaeocystis tank, and 1.0 $\mu \mathrm{M}$ in the Diatom tank (Passow et al. 2007, this issue). All mesocosms were kept at 12 to $14^{\circ} \mathrm{C}$ on a $16: 8 \mathrm{~h}$ light:dark cycle and were mixed using an air lift. Water samples were collected approximately every other day for $20 \mathrm{~d}$ to follow carbon dynamics in all 3 mesocosms. 
We started sampling $0.7 \mathrm{~d}$ after nutrient additions to the algal mesocosms. For simplification, the times in decimal dates have been rounded up to the nearest full day in the text, e.g. $0.7 \mathrm{~d}$ equals Day 1. For further details see Passow et al. (2007).

Dissolved organic carbon. For analysis of DOC, $10 \mathrm{ml}$ water samples were filtered through rinsed $0.2 \mu \mathrm{m}$ polycarbonate membranes (Nuclepore). The samples were then acidified with $100 \mu \mathrm{l}$ of $85 \% \mathrm{H}_{3} \mathrm{PO}_{4}$, flame sealed in combusted glass ampoules, and stored in the dark at $4{ }^{\circ} \mathrm{C}$ until measurement. DOC analysis was performed using high-temperature catalytic combustion (Shimadzu TOC5000). A 5-point calibration curve was constructed for calibration using potassium phthalate standards prepared freshly in UVtreated Milli-Q water. The standards covered a range

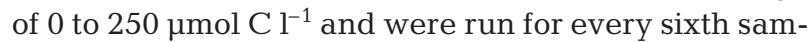
ple. All DOC concentrations are averages of at least 3 injections from each sample. The standard deviation between these injections was usually $<1 \%$. When a higher deviation occurred, the sample was run again. The instrument blank (8 to $12 \mu \mathrm{mol} \mathrm{l}^{-1}$ ) was measured using UV-treated Milli-Q water and was subtracted from each sample. Extreme care was taken to avoid carbon contamination. All glassware was combusted for $2 \mathrm{~h}$ at $550^{\circ} \mathrm{C}$, and Nuclepore filters were rinsed 3 times with ultra-pure UV-oxidized Milli-Q water.

Particulate organic carbon and nitrogen. Particulate organic carbon (POC) and nitrogen (PON) were measured in replicates from $100 \mathrm{ml}$ of water filtered onto pre-combusted GF/F filters (Whatman). Filters were rinsed with $2 \mathrm{ml}$ of UV-treated Milli-Q water after filtration to remove salt and were then kept frozen at $-20^{\circ} \mathrm{C}$ until analysis. POC and PON were measured by CHN-analysis (FlashEA 1112, Thermo Finnigan). The $\mathrm{C}: \mathrm{N}$ ratio of POM was calculated from the POC and PON measurements.

Determination of carbohydrates and amino acids was done by different methods, resulting in partly overlapping DOC fractions. To avoid confusion, we have listed the abbreviations of all analyzed DOC fractions in Table 1.

Dissolved carbohydrates. Colorimetric determination of dissolved monosaccharides (MCHO) and total dissolved carbohydrates (TCHO) in seawater were performed according to Myklestad et al. (1997) after condensation with the chromogen 2,4,6-tripyridyl-striazine (TPTZ). Then, $10 \mathrm{ml}$ aliquots of sample were filtered through combusted GF/F filters into com- busted glass vials and stored at $-20^{\circ} \mathrm{C}$ until analysis. Combined polysaccharides were hydrolyzed in $0.1 \mathrm{~mol}$ $\mathrm{l}^{-1} \mathrm{HCl}$ at $100^{\circ} \mathrm{C}$ for $20 \mathrm{~h}$ and analyzed as above. The concentration of dissolved combined carbohydrates (DCHO) was calculated by subtracting $\mathrm{MCHO}$ from TCHO. Each sample was measured in triplicate. The detection limit for glucose was $0.4 \mathrm{mg} \mathrm{l}^{-1}$, with a precision of $0.03 \mathrm{mg} \mathrm{l}^{-1}$. The carbon content of mono- and polysaccharides was calculated assuming a conversion of $30 \mu \mathrm{g}$ hexose $\mu \mathrm{mol}^{-1} \mathrm{C}$.

Neutral carbohydrates and amino acid. For the determination of dissolved neutral carbohydrates and amino acids, $10 \mathrm{ml}$ samples were filtered through rinsed $0.2 \mu \mathrm{m}$ pore size polycarbonate filters (Nuclepore) and stored at $-20^{\circ} \mathrm{C}$ until analysis. All measurements were performed in triplicate.

Prior to analysis, samples were desalted by ionexchange chromatography (Borch \& Kirchman 1999). Concentrations of dissolved free neutral carbohydrates (DFCHO) were analyzed according to Mopper et al. (1992), by HPLC (high-performance liquid chromatography) using a Carbopac PA 10 column (Dionex) and pulsed amperometric detection (PAD); $20 \mathrm{mmol} \mathrm{l}^{-1}$ $\mathrm{NaOH}$ was used as eluent. Dissolved combined neutral carbohydrates (DCCHO) were analyzed by HPLC as DFCHO after $20 \mathrm{~h}$ of hydrolysis in $0.09 \mathrm{~mol} \mathrm{l}^{-1} \mathrm{HCl}$ at $100^{\circ} \mathrm{C}$. Recovery of carbohydrate was checked by adding an external standard composed of 10 carbohydrates (fucose, desoxy-ribose, rhamnose, arabinose, galactose, glucose, xylose, fructose, ribose, saccharose) after every fifth sample.

For determination of amino acids by HPLC, $10 \mathrm{ml}$ samples were filtered through $0.22 \mu \mathrm{m}$ pore size acrodisc syringe filters with low protein binding affinity (Pall Corporation) and stored at $-20^{\circ} \mathrm{C}$. Concen- 
trations of dissolved free amino acids (DFAA) were analyzed by HPLC after ortho-phthaldialdehyde derivatization (OPA) (Lindroth \& Mopper 1979). Dissolved combined amino acids (DCAA) were hydrolyzed with $6 \mathrm{~mol} \mathrm{l}^{-1} \mathrm{HCl}$ at $155^{\circ} \mathrm{C}$ for $1 \mathrm{~h}$ and analyzed as DFAA. Samples for particulate combined amino acids (PCAA) were unfiltered and analyzed after acid hydrolysis in the same manner as for DCAA.

Net and gross community production. Net and gross community production rates were approximated from oxygen evolution in bottle incubations. Dissolved oxygen was determined based on the method by Winkler using automated titration (Titrino, Metrohm) and potentiometric endpoint detection. Water was sampled from the mesocosms through a Tygon tube directly into $300 \mathrm{ml}$ glass bottles (BOD) and incubated immediately. Two dark and 2 light bottle incubations were performed for $6 \mathrm{~h}$. Initial oxygen concentration was determined immediately from 2 additional bottles. Both daily gross production (GP) and daily net community production (NPP) were calculated according to Engel et al. (2002); GP ( $\mu$ mol $\mathrm{C} \mathrm{l}^{-1} \mathrm{~d}^{-1}$ ) is defined as gross production within the $16 \mathrm{~h}$ of illumination, and NPP

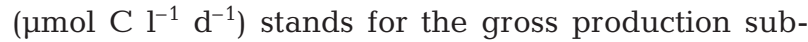
tracted by respiration (including light and dark respiration during the $16 \mathrm{~h}$ of illumination and the remaining $8 \mathrm{~h}$ of darkness). Daily oxygen production was corrected by the oxygen produced during $\mathrm{NO}_{3}{ }^{-}$uptake, because reduction of $\mathrm{NO}_{3}$ to $\mathrm{NH}_{4}$ within the cell generates $2 \mathrm{~mol} \mathrm{O}_{2}$. The $\mathrm{NO}_{3}{ }^{-}$uptake per day was assumed to be equal to the decrease of $\mathrm{NO}_{3}{ }^{-}$concentration in the mesocosm on that day. The molar ratio of oxygen production to carbon assimilation was assumed to be 1.08 after Laws (1991). Mesocosms were defined as net heterotrophic when net respiration surpassed net photosynthetic production and autotrophic when net photosynthetic production exceeded net respiration.

Carbon budgets. Carbon budgets were calculated for the period between Day 4 and the end of the experiment (Day 20). The missing carbon was calculated for each mesocosm as the residual missing carbon taking into account loss and gain in NPP, DOC, and POC. This fraction may include loss of carbon by sedimentation, accumulation of buoyant organic matter at the surface, or other unknown processes. Each variable was plotted against time to calculate a regression and its slope. If the regression was significant $(p<0.1)$, the slope was multiplied by the time of the experimental period. Net changes of POC and NPP, however, were calculated cumulatively.

Statistical analyses. Statistical analyses were done by 'post hoc' standard least square contrast analyses after ANCOVA, with time as the covariate and mesocosm as the nominal predictor. All statistical analyses were performed with the software JMP 4.02 using average values since no parallel mesocosms were run. Significance was given at values $\mathrm{p}<0.05$. We also separately performed the same statistical analyses for the lag (Days 1 to 8) and the exponential/stationary phase (Days 10 to 20) of the algal bloom. At that time both organic matter and bacterial community composition (Murray et al. 2007, this issue) in the algal mesocosms shifted significantly. Since we only had 4 time points for the pre-bloom but 6 time points for the later phases of the bloom, the resulting significance levels for all measurements in the pre-bloom phase are rather uncertain. However, in the pre-bloom phase, levels of significance were significantly different only for algalrelated parameters such as chlorophyll a (chl a), POC, and NPP and, hence, are not given separately.

For qualitative comparison of DOC pools, all DFCHO, DCCHO, DFAA, and DCAA data were clustered in 2 dimensions. Clustering was done using the freeware 'Cluster' v. 2.11 by using a Pearson's correlation matrix of all data given in percent of DOC. The respective tree was constructed in Tree View v. 1.60 (http://rana.lbl.gov).

\section{RESULTS}

\section{General bloom dynamics}

Whereas phytoplankton concentrations in the No Addition tank remained negligible during the investigation, a small bloom developed in the Phaeocystis tank, with peak chl a concentrations of $2 \mu \mathrm{g} \mathrm{l}^{-1}$ on Days 12 and 14. A large bloom developed in the Diatom tank, with chl a concentrations reaching $55 \mu \mathrm{l}^{-1}$ by the end of the investigation (Passow et al. 2007). Throughout the incubation, concentrations of chl a were significantly higher in the Diatom tank $(\mathrm{p}<0.001$, $\mathrm{n}=10$ ), but were not significantly different between the No Addition and Phaeocystis tanks, even when excluding the pre-bloom phase (Days 1 to 8).

\section{Net primary production}

NPP rate (Fig. 1) was negative throughout the study in the No Addition tank, indicating that this mesocosm was a highly heterotrophic system. In the Phaeocystis tank, NPP was negative initially and increased to only

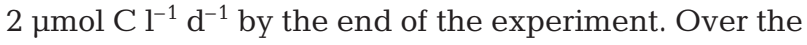
course of the experiment no total net production was obtained in this mesocosm. In contrast, the NPP rate increased significantly during the bloom in the Diatom

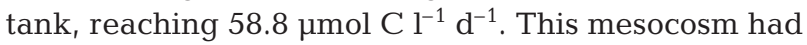

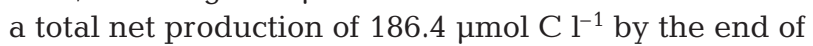
the study. 


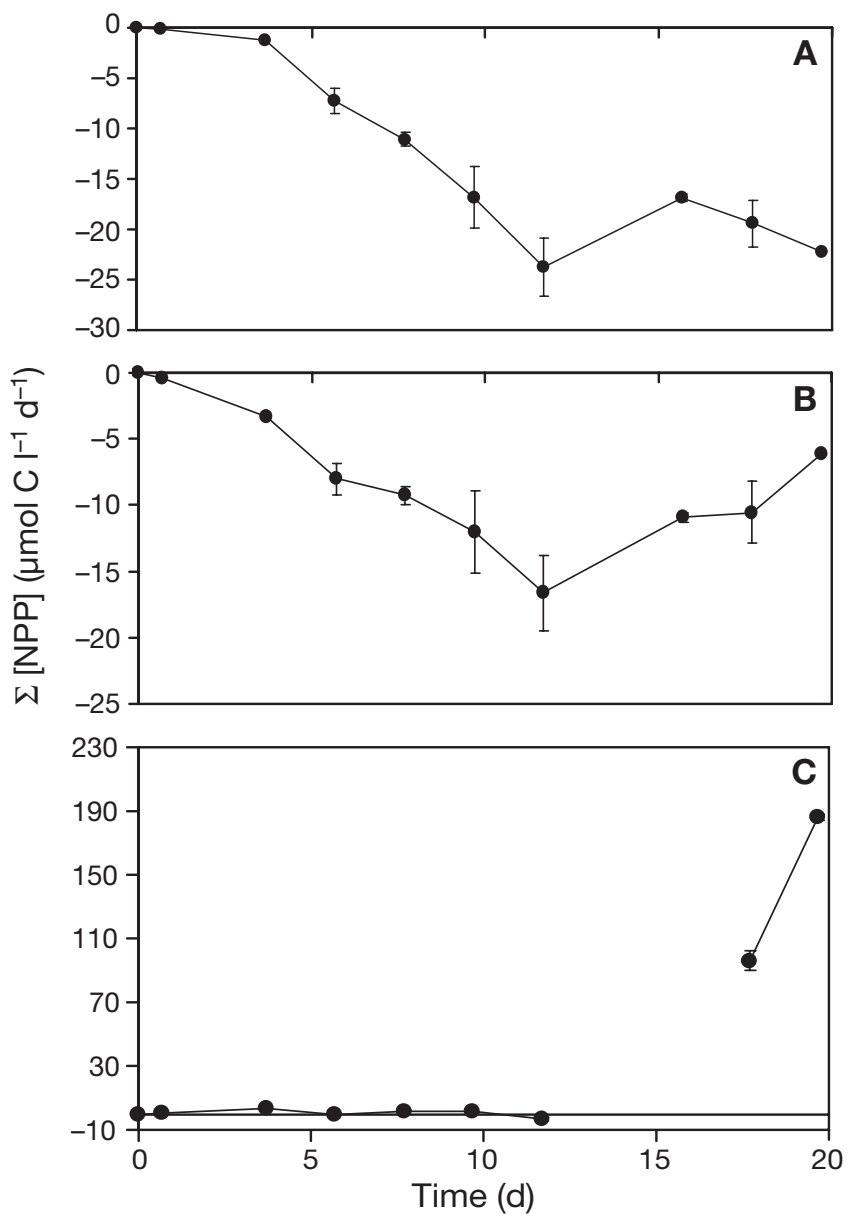

Fig. 1. Cumulative display of net primary production (NPP) in the (A) No Addition, (B) Phaeocystis, and (C) Diatom tanks

\section{Community respiration}

Oxygen consumption in the dark was highly variable over time in all mesocosms, with values of 0.1 to $1.2 \mu \mathrm{mol} \mathrm{O} \mathrm{O}_{2} \mathrm{l}^{-1} \mathrm{~d}^{-1}$. However, average oxygen consumption was remarkably similar in all mesocosms, yielding $0.4 \pm 0.2,0.3 \pm 0.3$, and $0.4 \pm 0.4 \mu \mathrm{mol} \mathrm{O} \mathrm{O}_{2} \mathrm{l}^{-1}$ $\mathrm{d}^{-1}$ for the No Addition, Phaeocystis, and Diatom tanks, respectively.

\section{Dissolved organic carbon}

The initial concentration of DOC of the sampled

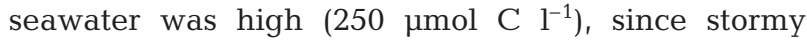
weather had pushed the plume of the Elbe River to the sampling site near Helgoland (see Passow et al. 2007). After $1 \mathrm{~d}$ of incubation, the DOC concentration had only decreased a little in the No Addition tank (236 $\left.\mu \mathrm{mol} \mathrm{C}^{-1}\right)$, but much more in both algal meso-

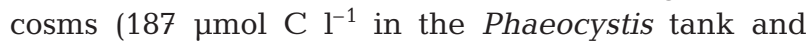

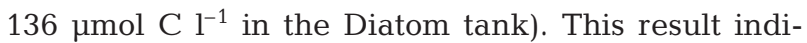
cates that the addition of algal cultures greatly affected DOC dynamics at the beginning of the experiment. DOC concentrations in the No Addition tank showed an overall decreasing trend until the

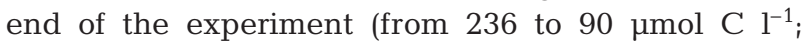
Fig. 2A). In the Phaeocystis and Diatom tanks, however, it declined until Day 14 of the experiment, to 76 and $66 \mu \mathrm{mol} \mathrm{C} \mathrm{l}^{-1}$, respectively, but thereafter

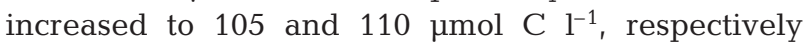
(Fig. 2A). Although the temporal dynamics of DOC concentrations differed between mesocosms, they were not significantly different (Table 2).

\section{Particulate organic carbon}

Concentrations of POC in the No Addition tank remained negligible over the duration of the experiment (Fig. 2B). In the Phaeocystis tank, POC showed

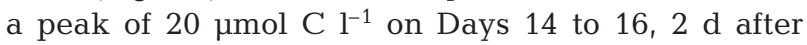
the peak in chl a concentrations. POC increased steadily in the Diatom tank, as did chl $a$, reaching

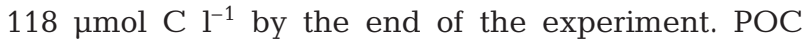
concentrations were significantly different between the Diatom tank and the No Addition or Phaeocystis tanks (Table 1), indicating that POC in the Diatom tank was mainly of algal origin.
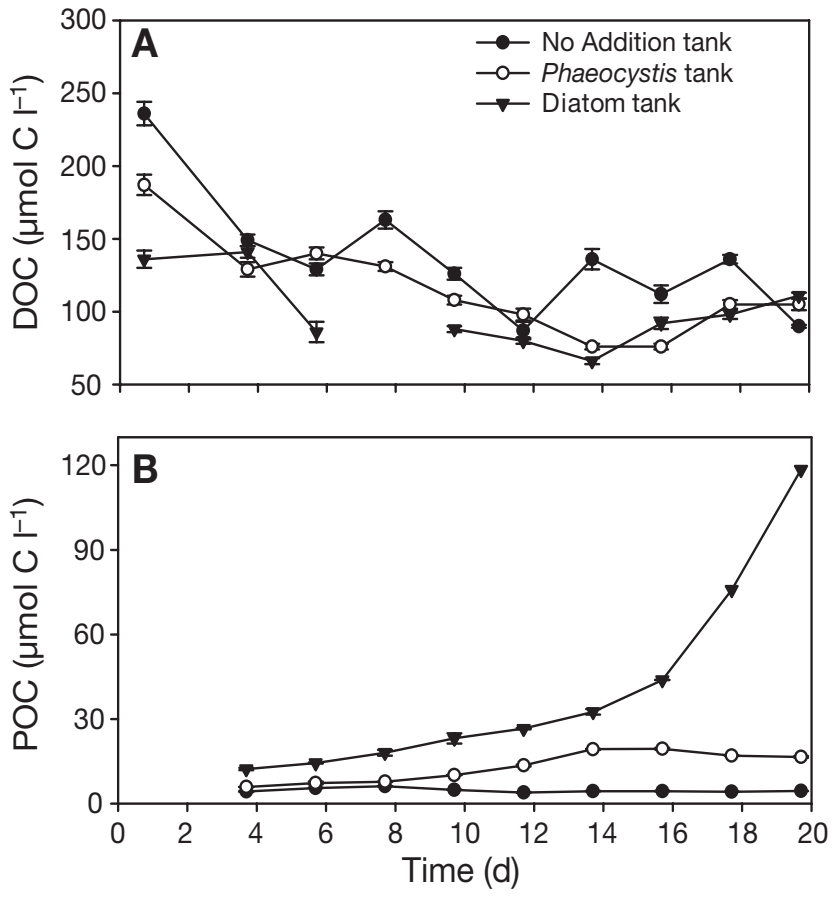

Fig. 2. Temporal course of concentrations of (A) dissolved organic carbon (DOC) and (B) particulate organic carbon (POC) in the No Addition, Phaeocystis, and Diatom tanks 
Table 2. Statistical analyses using 'post hoc' analyses after ANCOVA with time as the covariate and mesocosm as the nominal predictor. All statistical analyses were performed with the software JMP 4.02. NA, P, and D: No Addition, Phaeocystis, and Diatom tanks, respectively. ns: not significant; DOC: dissolved organic carbon; POC: particulate organic carbon; NPP: net primary production; other abbreviations as in Table 1

\begin{tabular}{|c|c|c|c|c|c|c|c|c|c|c|c|}
\hline Tank & DOC & $\mathrm{POC}$ & $C: N$ & $\mathrm{MCHO}$ & $\mathrm{TCHO}$ & DFCHO & $\mathrm{DCCHO}$ & DFAA & DCAA & PCAA & NPP \\
\hline \multicolumn{12}{|l|}{ Variables } \\
\hline NA vs. P & ns & ns & ns & ns & ns & 0.0063 & ns & 0.0147 & ns & ns & ns \\
\hline NA vs. D & ns & $<0.0002$ & ns & ns & ns & 0.0013 & ns & ns & ns & 0.00124 & $<0.0001$ \\
\hline P vs. D & ns & $<0.0025$ & ns & ns & ns & ns & ns & ns & ns & 0.00539 & 0.0002 \\
\hline \multicolumn{12}{|c|}{ Whole model of variance } \\
\hline & ns & 0.0005 & ns & ns & ns & 0.0029 & ns & 0.048 & ns & 0.0024 & $<0.0001$ \\
\hline
\end{tabular}

\section{Dissolved monosaccharides and total dissolved carbohydrates}

In all mesocosms - even in the No Addition tank $\mathrm{MCHO}$ were highly variable and did not show any trend over time (Fig. 3A). Concentrations of $\mathrm{MCHO}$ in the Phaeocystis and Diatom tanks were higher than in the No Addition tank, reaching maxima of 2.94 and $2.48 \mu \mathrm{mol}$ hexose $\mathrm{l}^{-1}$, respectively. Concentrations of $\mathrm{MCHO}$ in the Phaeocystis tank were positively correlated with chl a concentrations $\left(\mathrm{r}^{2}=0.79\right.$; $\left.\mathrm{p}<0.001\right)$ and slightly negatively correlated with heterotrophic nanoflagellate abundances $\left(\mathrm{r}^{2}=0.57, \mathrm{p}<0.05\right)$. $\mathrm{MCHO}$ in the Diatom tank were not correlated with any of the above-mentioned parameters. Over the whole incubation, neither $\mathrm{MCHO}$ nor TCHO values were significantly different among the mesocosms (Table 2).

TCHO values were significantly higher in the Phaeocystis tank than in the No Addition $(\mathrm{p}<0.001, \mathrm{n}=6)$ or Diatom tanks ( $\mathrm{p}=0.0191, \mathrm{n}=6$ ) when the pre-bloom phase was excluded (also see Fig. 3B). In the No Addition tank, concentrations of TCHO ranged from 2.8 to $4.3 \mu \mathrm{mol}$ hexose $\mathrm{l}^{-1}$ throughout the experiment, without any clear temporal trend. TCHO in the Phaeocystis tank reached a notable maximum of $6.4 \mu \mathrm{mol}$ hexose $\mathrm{l}^{-1}$ on Day 10, just before the peak in chl a. Concentrations of TCHO in the Diatom tank increased without interruption from Day 10, reaching $4.8 \mu \mathrm{mol}$ hexose $\mathrm{l}^{-1}$ by the end of the experiment.

\section{Neutral carbohydrates}

Concentrations of DFCHO were significantly higher in the No Addition tank than in the Phaeocystis or Diatom tanks (Table 2) and continuously increased in all mesocosms over time (Fig. 4A). This suggests differences in production and microbial utilization of DFCHO among the different mesocosms.

Concentrations of DCCHO in the No Addition tank varied between 0.49 and $1.17 \mu \mathrm{mol}^{-1}$ and in the Phaeo- cystis tank between 0.5 and $1.73 \mu \mathrm{mol}^{-1}$. In the Diatom tank they remained rather constant at ca. $1 \mu \mathrm{mol} \mathrm{l}^{-1}$ throughout the whole experiment. DCCHO did not significantly differ among the mesocosms (Fig. 4B, Table 2).

\section{Amino acids}

DFAA concentrations were lowest in the No Addition tank, varying between 0.01 and $0.05 \mu \mathrm{mol} \mathrm{l}^{-1}$
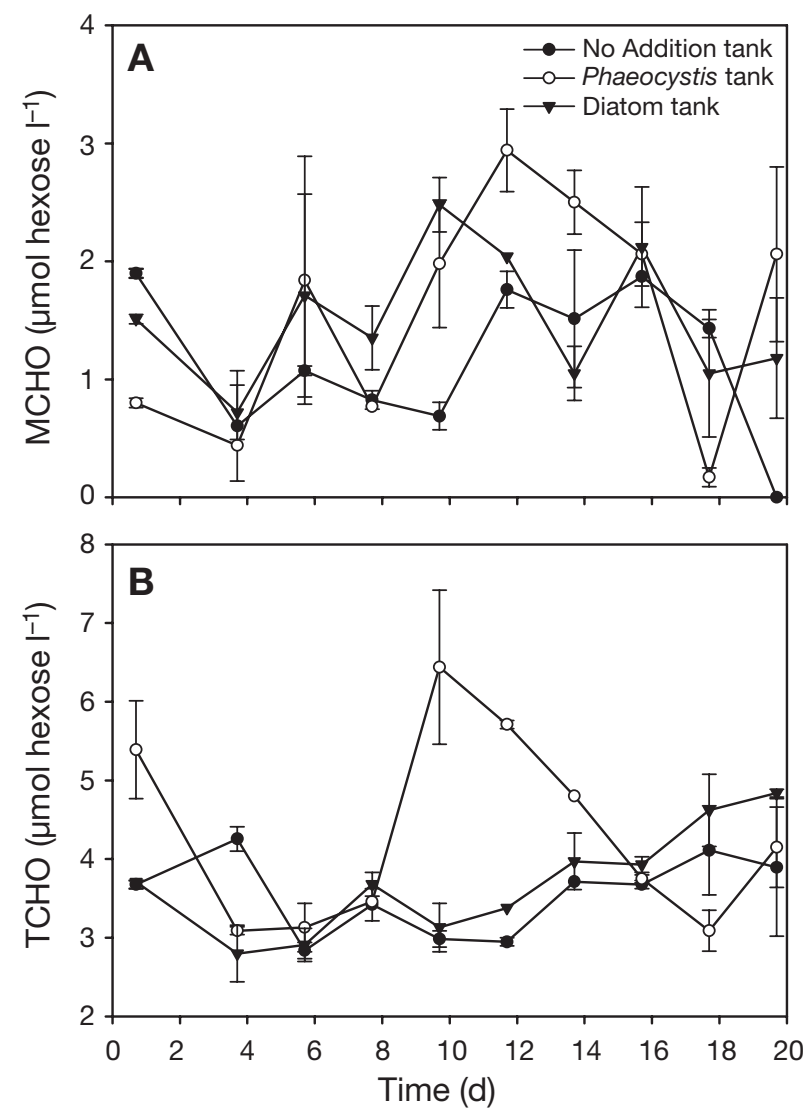

Fig. 3. Temporal course of (A) dissolved free (MCHO) and (B) total dissolved carbohydrates (TCHO) measured using the TPTZ method (see Table 1) 

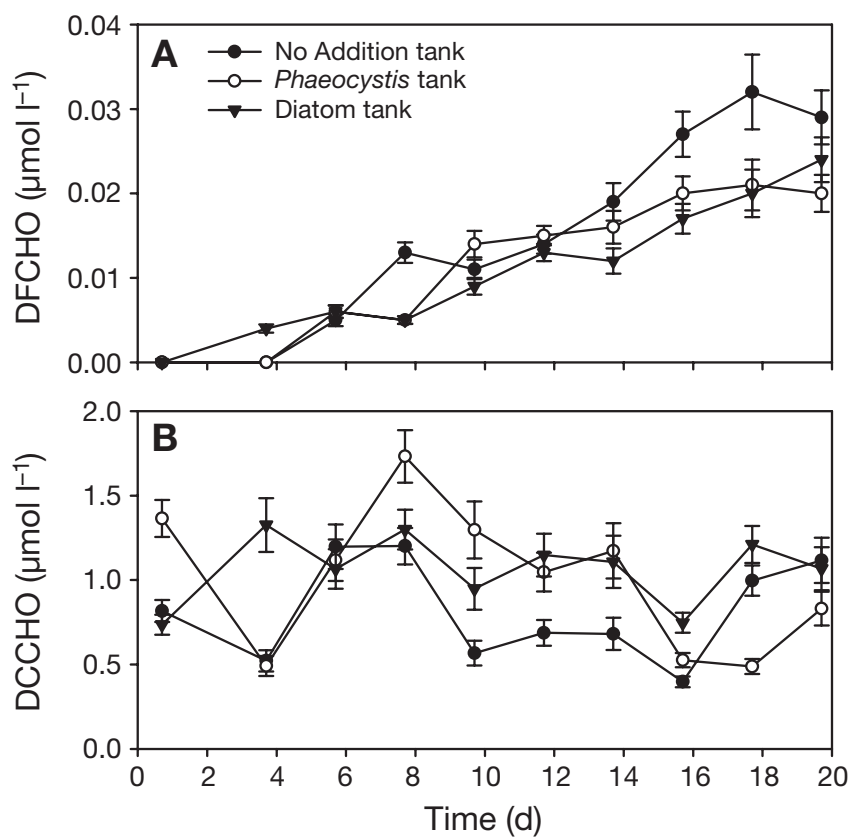

Fig. 4. Temporal course of (A) dissolved free (DFCHO) and (B) dissolved combined neutral carbohydrates (DCCHO) measured using the HPLC-PAD technique (see Table 1)

(Fig. 5A). In the Phaeocystis tank they were significantly higher and increased from $0.02 \mu \mathrm{mol} \mathrm{l}^{-1}$ on Day 10 to $0.22 \mu_{\mathrm{mol} \mathrm{l}} \mathrm{l}^{-1}$ on Day 18 (Table 2). Concentrations of DFAA in the Diatom tank peaked at $0.23 \mu \mathrm{mol} \mathrm{l}^{-1}$ (Day 14), but this peak is anomalously high against a range of Diatom tank DFAA values of only $0.04 \pm$ $0.02 \mu \mathrm{mol} \mathrm{l}^{-1}$. If this anomalous value is excluded, DFAA concentrations in the Diatom tank were also significantly lower than in the Phaeocystis tank ( $\mathrm{p}=$ 0.0057, $\mathrm{n}=9$ ).

Concentrations of DCAA, close to $3.5 \mu \mathrm{mol} \mathrm{l}^{-1}$ in all mesocosms, were much higher than DFAA. Neither consistent temporal trends, nor significant differences in DCAA concentrations were observed among the mesocosms (Fig. 5B, Table 2).

Concentrations of PCAA in the No Addition tank were low (0.06 to $0.09 \mu \mathrm{mol} \mathrm{l}^{-1}$ ) and did not change greatly over time (Fig. 5C). They were slightly, but not significantly, higher in the Phaeocystis tank (0.07 to $0.30 \mu \mathrm{mol} \mathrm{\textrm {l } ^ { - 1 }}$ ), whereas PCAA concentrations were highest in the Diatom tank, where they attained a maximum of $1.93 \mu \mathrm{mol} \mathrm{l}^{-1}$ by the end of the experiment (Fig. 5C, Table 2). PCAA concentrations in all mesocosms paralleled those of POC (Fig. 2B).

\section{Carbon budgets}

Carbon budgets calculated for the period between Days 4 and 20 (Fig. 6) were negative for almost all
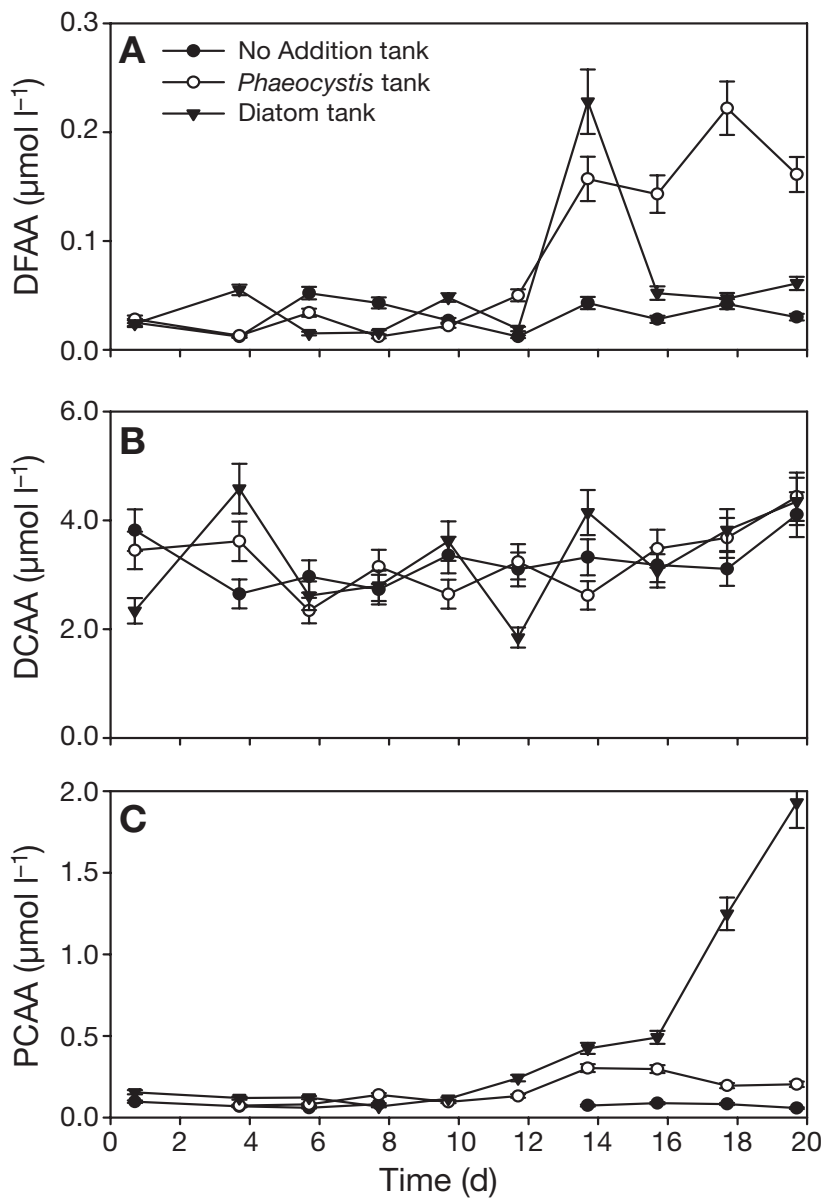

Fig. 5. Temporal course of (A) dissolved free (DFAA), (B) dissolved combined (DCAA), and (C) particulate combined amino acids (PCAA) measured using the HPLC-OPA technique (see Table 1)

parameters (NPP, DOC, and missing carbon) in the No Addition tank, where the carbon loss due to the decrease in DOC was higher than the missing carbon, which includes DOC losses due to sedimentation and/or accumulation at the surface. A similar pattern occurred in the Phaeocystis tank, except that NPP was much higher, although still negative. However, a slight net accumulation of POC occurred, possibly supported by the transformation of DOC into POC through microbial uptake or abiotic particle formation. In the Diatom tank there was a high level of carbon production through autotrophic processes, i.e. NPP, which resulted in high accumulation of POC. In this mesocosm, the missing fraction of carbon exceeded that of DOC drawdown and was significantly higher than that in the other 2 mesocosms. The silica budget in the Diatom tank indicates that the high amount of missing carbon was mainly due to sedimentation (Passow et al. 2007).

The increase in DFCHO in all mesocosms was not reflected by changes in the DOC pool. No net changes 
were evident in concentration of $\mathrm{DCCHO}$, non-neutral carbohydrates [other $\mathrm{DCHO}=\mathrm{TCHO}-(\mathrm{DCCHO}+$ DFCHO)], or DFAA in the No Addition tank, whereas DCAA greatly increased (Fig. 7). In contrast, DCCHO in the Phaeocystis tank greatly decreased during the

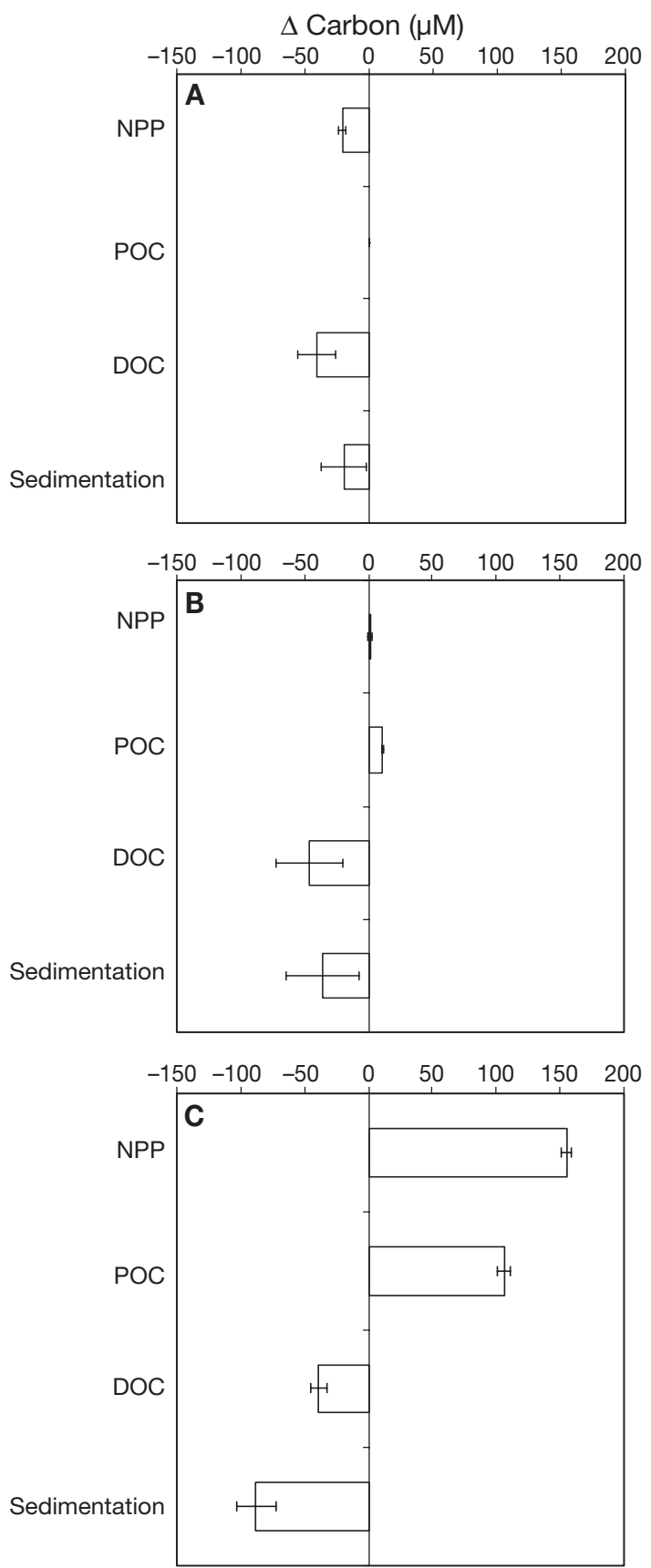

Fig. 6. Carbon budgets for net primary production (NPP), particulate (POC) and dissolved organic carbon (DOC), and sedimentation in the (A) No Addition, (B) Phaeocystis and (C) Diatom tanks. Sedimentation was calculated for each mesocosm as the residual missing carbon taking into account loss and gain in NPP, DOC, and POC. Calculations include the time between 3.7 and $19.7 \mathrm{~d}$ observation period, whereas other DCHO, DFAA, and also DCAA increased. In the Diatom tank DCAA and, in particular, other DCHO increased.

\section{TCHO, DFCHO, and DCCHO, and amino acids as percent of DOC or POC}

In all mesocosms, dissolved TCHO accounted for the highest percentages of DOC, followed by amino acids and DCCHO (Fig. 8). TCHO increased from 10 to almost $25 \%$ by the end of the experiment in the No Addition tank, while dissolved amino acids increased from 9 to $21 \%$ and DCCHO (a fraction of TCHO) from 2 to $6 \%$ of DOC. In the Phaeocystis tank, percentages of TCHO between Days 10 and 16 were appreciably higher $(37 \%)$ than in the No Addition tank and the percentage of DCAA increased almost continuously from 10 to $21 \%$ of DOC. Between Days 8 and 14, percentages of DFCHO and DCCHO in the Phaeocystis tank were higher than in the No Addition tank, reaching $8 \%$ at maximum. In the Diatom tank, percentages of TCHO, DFCHO and DCCHO, and amino acids peaked on Day 14 at 35,10 , and $32 \%$ of DOC, respectively. In general, percentages of both TCHO and amino acids were highly variable in time. Particulate amino acids contributed only to $5-8 \%$ of POC and did not greatly differ among the mesocosms (Fig. 8).

\section{Comparison of treatments by qualitative changes of specific DOC fractions}

Cluster analysis based on individual DFCHO, DCCHO, DFAA, and DCCA values given as percentages of DOC revealed significant differences between the No Addition and algal tanks after the strong drawdown of the initial DOC pool (Fig. 9). Except for Day 16, all samples of the No Addition tank after Day 6 (the drawdown of the initial DOC pool) formed a uniform cluster distinct from that of the Phaeocystis and Diatom tanks. Whereas differences of Diatom samples between Days 4 and 18 were rather small, those of Phaeocystis samples between Days 6 and 20 were more pronounced, indicating a higher temporal variability in DOC composition.

Glucose and rhamnose together accounted for a significant portion of the total DOC pool in almost all samples after Day 4 (Fig. 9); they were also the major constituents of DFCHO monomers. Solely in Diatom samples, dissolved free glucose contributed to a significantly lower portion of DOC compared to the No Addition and Phaeocystis tanks. Galactose, glucose, and mannose were the major DCCHOs in all mesocosms. Whereas the proportion of glucose remained 
similar in all treatments over time, the proportion of mannose was much lower in Phaeocystis samples between Days 10 and 14. In contrast, the proportion of galactose was highly variable and did not show any consistent pattern either with time or with treatment.

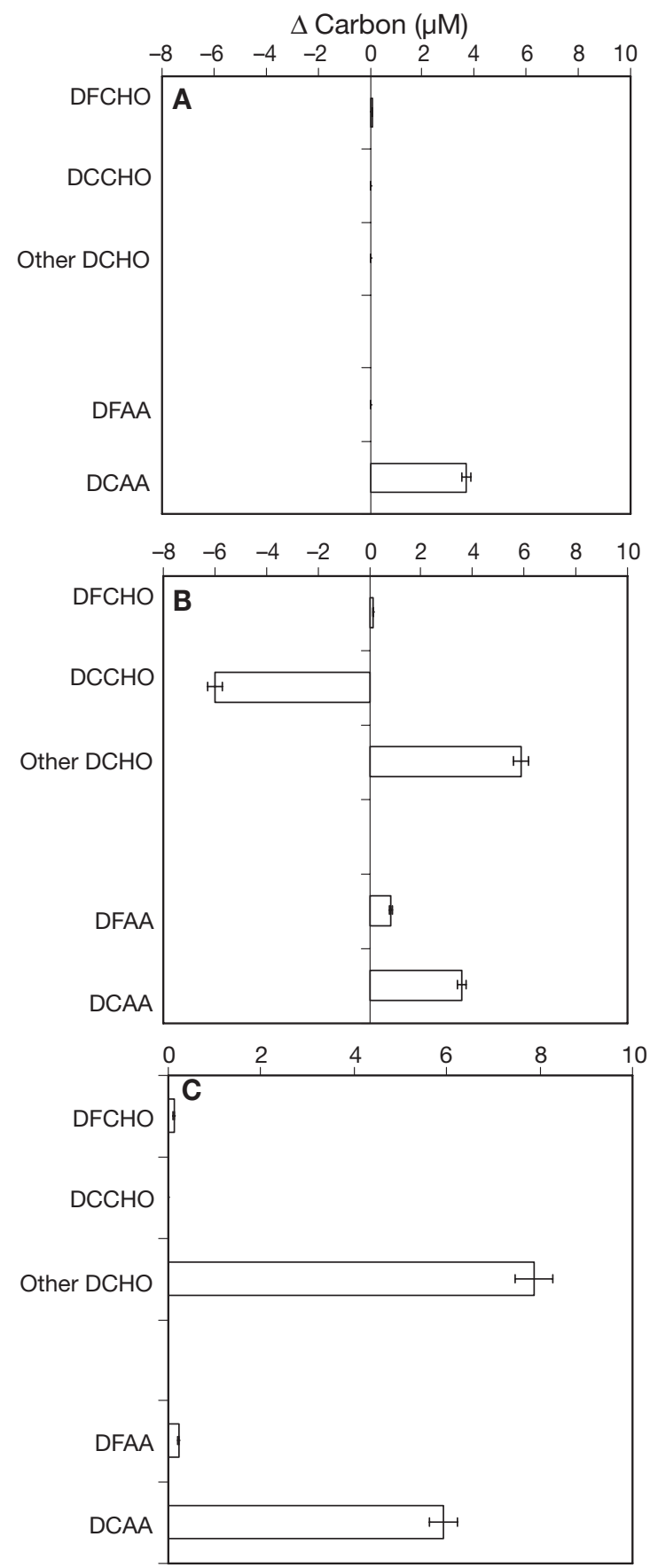

Fig. 7. Carbon budgets for measured fractions of DOC: dissolved free (DFCHO) and combined neutral carbohydrates (DCCHO), other DCHO [TCHO - (DCCHO + DFCHO $)]$, dissolved free (DFAA) and combined amino acids (DCAA) in the (A) No Addition, (B) Phaeocystis and (C) Diatom tanks. Calculations include the time between 3.7 and $19.7 \mathrm{~d}$
Glutamate and serine were the most prominent DFAAs (Fig. 9), contributing to substantial fractions of the total DOC pool. The overall contribution of dissolved free alanine was lower, but it was high in all Phaeocystis samples after Day 8. Dissolved free
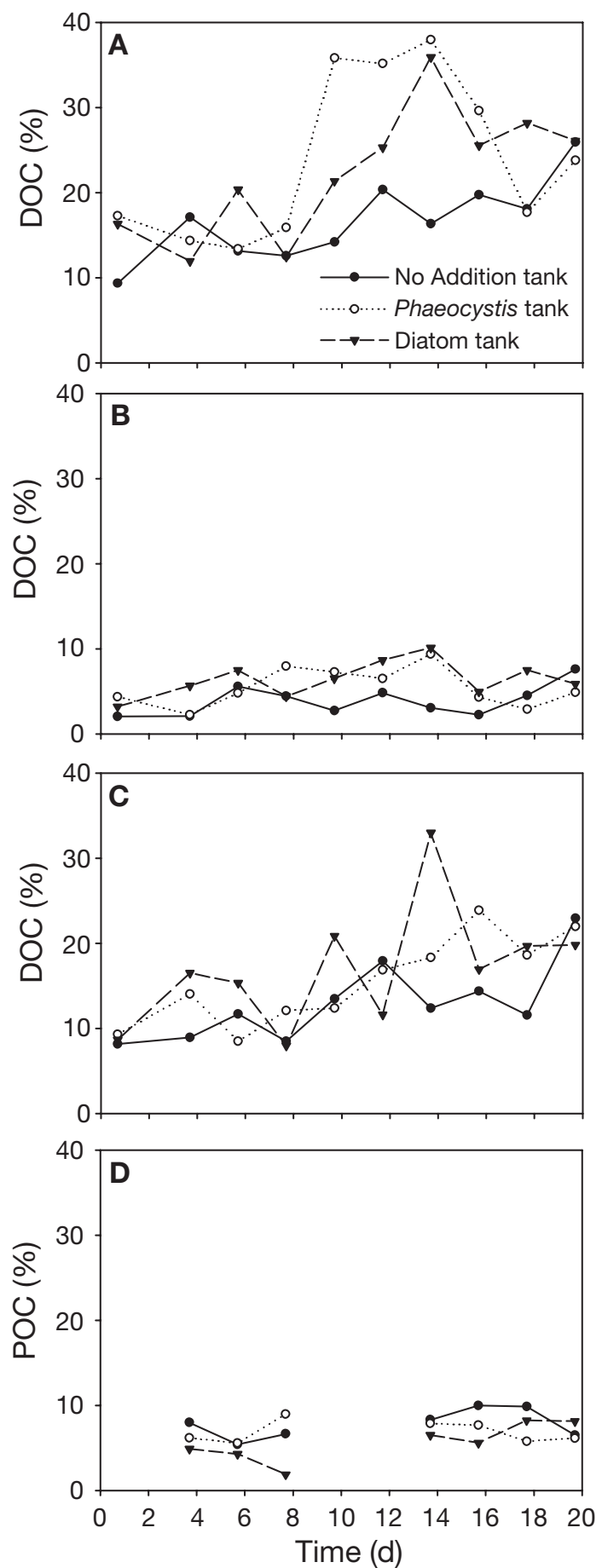

Fig. 8. (A) Total dissolved carbohydrates (TCHO), (B) dissolved neutral carbohydrates (DCCHO) and (C) dissolved amino acids (DCAA) given as percent of DOC, as well as (D) and particulate amino acids (PCAA) given as percent of POC 


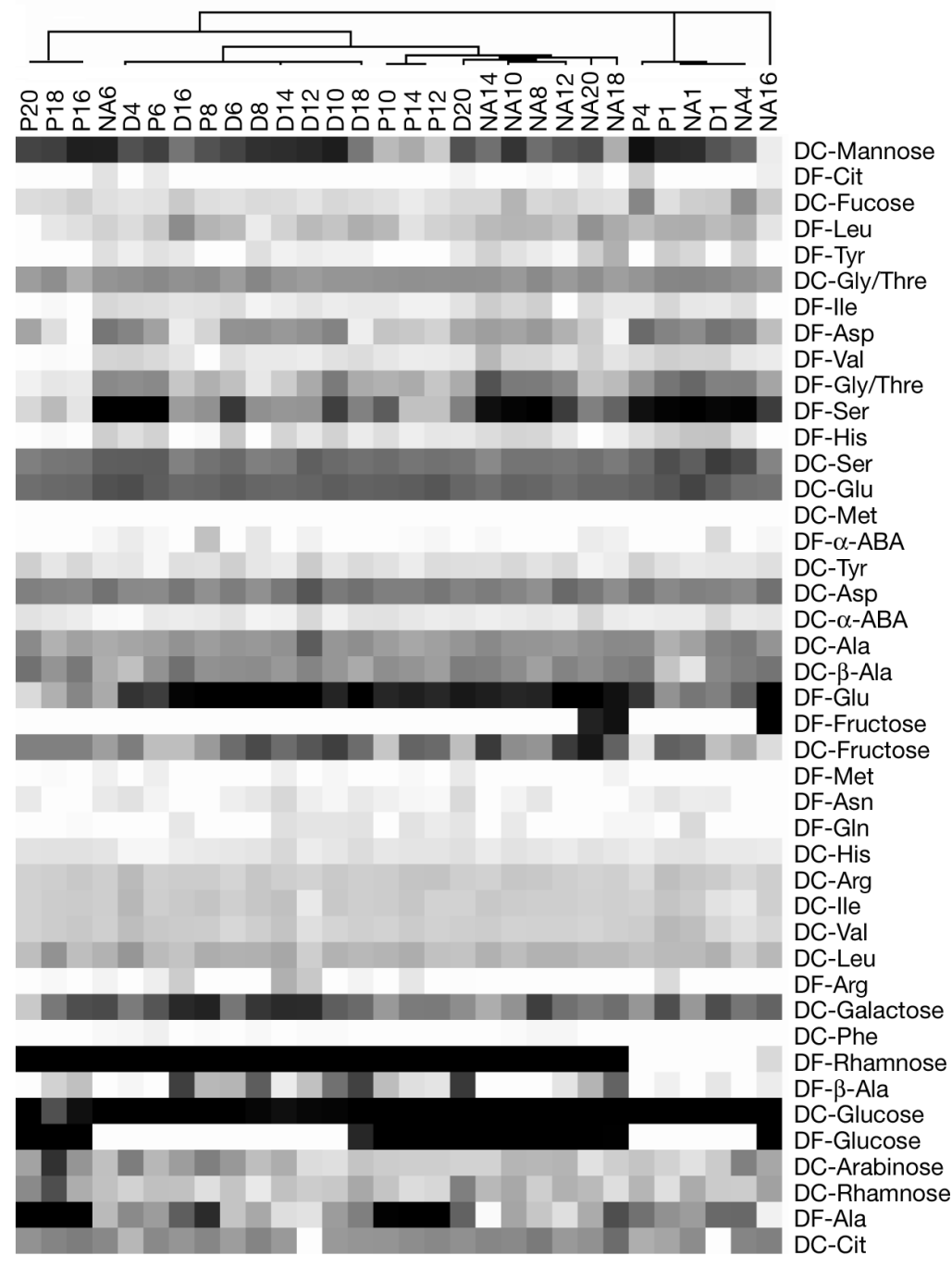

Fig. 9. Qualitative comparison of DOC fractions (DFCHO, DCCHO, DFAA, and DCAA) by 2-dimensional cluster analysis using a Pearson's correlation matrix of all data given in percent of DOC. Relative concentration of DOC fractions (low to high) is shown as a white to black gradient. Cluster dendrogram at the top shows the relatedness between mesocosm samples labeled with the mesocosm followed by sample date. DF: dissolved free; DC: dissolved combined carbohydrates (fucose, rhamnose, arabinose, galactose, glucose, mannose, fructose) or amino acids (Asp: aspartate; Asn: asparagine; Glu: glutamate; Gln: glutamine; His: histidine; Ser: serine; Cit: citrulline; Gly/Thre: glycine/ threonine; Arg: arginine; Ala: alanine; $\beta$-Ala: $\beta$-alanine; Tyr: tyrosine; Met: methionine; Val: valine; Phe: phenylalanine; Ile: isoleucine; Leu: leucine)

aspartate was of minor importance and contributed to significantly higher proportions of the DOC pool in all samples until Day 4 and most of the No Addition samples. Glutamine/glutamate, asparagine/aspartate, and serine dominated the DCAAs and contributed to a significant proportion of total DOC (Fig. 9). None of these amino acids showed any significant change over time or differences between treatments.

\section{DISCUSSION}

\section{Carbon budgets}

Our mesocosm set up differs from previous laboratory pure culture experiments by the rather large water volume, which allows minimization of so-called 'bottle effects'. The mesocosms of this study represented 3 situations in which pronounced differences in DOM dynamics were likely to occur. The prevalence of respiration over net community production in the No Addition tank demonstrates that this mesocosm was a net heterotrophic system (Fig. 6). The Phaeocystis tank was a more balanced system, showing slight gains in NPP and POC, but slightly greater losses in DOC and carbon most likely due to sedimentation. Lastly, the Diatom tank was a strongly productive system, with a notable bloom and levels of NPP and POC production that far surpassed Closses by respiration and other processes (e.g. sedimentation, spontaneous coagulation, and particle formation [Engel et al. 2004], as well as accumulation of buoyant carbon at the surface; Fig. 6). Our measurements may have been biased by the fact that some microparticles and microorganisms pass through GF/F filters, but not through the $0.2 \mu \mathrm{m}$ polycarbonate membranes. Thus, some fractions of microparticles and microorganisms $(<0.7$ to $0.2 \mu \mathrm{m})$ do not appear in our calculations. Assuming an average bacterial carbon content of $20 \mathrm{fg} \mathrm{C}$ cell $^{-1}$, bacteria (also including those $>0.7 \mu \mathrm{m}$ ) may contribute to a maximum of $1 \mu \mathrm{mol}$ $\mathrm{Cl}^{-1}$, which equals, on average, $20 \%$ of the POC pool in the No Addition tank, but only 7.7 and $2.5 \%$ of the POC in the Phaeocystis and Diatom tanks, respectively. Taking these rough estimations and our data on microparticles into account, we believe that-at least for the algal mesocosms - our carbon budgets are realistic.

Although all 3 mesocosms showed a net decline in DOC concentrations, as measured by high-temperature catalytic combustion, the composition of DOC, as elucidated by HPLC, occurred in a substantially different fashion in each of the 3 mesocosms. While all 3 mesocosms showed significant gains in DFAA and 
DCAA and minor gains in DFCHO, only the algal mesocosms showed gains in non-neutral dissolved carbohydrates, and only the Phaeocystis tank showed losses of DCCHO. In the No Addition and Diatom tanks, the net decrease in DOC measured by hightemperature catalytic combustion occurred in dissolved materials that were not tracked by the HPLCbased methods utilized here (Lindroth \& Mopper 1979, Mopper et al. 1992). In the Phaeocystis tank, however, it was DCCHO that substantially decreased.

Even though the budgets differed between mesocosms, DOC dynamics in all mesocosms could only be explained to a minor degree by dissolved carbohydrates and amino acid measurements. It may be that our methods did not fully detect all carbohydrates and amino acids present. The TPTZ method, for example, does not have uniform sensitivity for different carbohydrates. L-rhamnose, L-fucose, D-galacturonic acid, and D-mannuronic acid are known to be difficult to detect by this method (Myklestad et al. 1997). However, TCHO, as measured by this method, amounts to a considerable DOC fraction (up to $38 \%$, see below), which suggests that most of the carbohydrates were detected by our analytical techniques. Other organic molecules, such as fatty acids (Canuel \& Zimmerman 1999) and complex organic molecules, which were not detected by any of the methods used, may have also contributed major fractions to the DOC pool and been responsible for the observed drop in total DOC.

In none of the experiments was there a distinct accumulation of DOC that could be attributed unequivocally to phytoplankton release. Nonetheless, there are indications that phytoplankton input to the DOC was occurring. The increase of TCHO in the Phaeocystis tank between Days 8 and 16 and the relative increase of TCHO as percent of DOC at that time in both algal mesocosms were all likely due to release by phytoplankton. Additionally, DOC concentrations in both algal mesocosms either increased during bloom development (Diatom tank) or during its break down (Phaeocystis tank). The clearly different composition of DOC and the shift in bacterial community composition (Murray et al. 2007) in all mesocosms between Days 6 and 10 indicate that changes in DOC quality were linked to algal and also microbial dynamics.

Accumulation of DOC with the development and degradation of phytoplankton blooms has been previously observed (e.g. Carlson et al. 1998, Børsheim et al. 1999, Meon \& Kirchman 2001). There are several indications that a similar accumulation of phytoplanktonproduced DOC in our experiment was prevented by high bacterial growth that can be attributed to the high initial concentrations of DOC and nutrients (Murray et al. 2007). In addition, none of the mesocosms was fully depleted in nutrients (Passow et al. 2007); hence, exu- dation rates of algal DOC would have most likely been small relative to rates observed in studies made under conditions of nutrient limitation (Obernosterer \& Herndl 1995, Biddanda \& Benner 1997, Søndergaard et al. 2000). Small changes in DOC concentration due to the release of labile DOC would have been invisible against the high background concentrations of initial DOC $\left(<150 \mu \mathrm{mol} \mathrm{l}^{-1}\right)$. In addition, DOC released by phytoplankton may have been quickly degraded by bacterial activities. The drawdown of DOC concentrations at the beginning of the experiment indicates that rapid bacterial degradation of labile DOC (Smith et al. 1992, Myklestad 1995) was occurring in all 3 mesocosms. This drop in DOC was followed by a marked increase in bacterial numbers and hydrolytic activities (Murray et al. 2007).

Interestingly, the fraction of dissolved free glucose increased from Days 1 to 20 in all experiments, whereas that of dissolved combined glucose decreased. This notion may point to the fact that the observed increase in bacterial abundance led to high hydrolytic activities that were partly decoupled from bacterial uptake of carbohydrate monomers. This has been previously observed for macroscopic organic aggregates (Smith et al. 1992, Grossart \& Simon 1998) and for bacteria attached to diatoms (Grossart et al. 2006).

\section{Composition of DOC}

Total carbohydrates and amino acids formed a major part of the DOC, accounting for 25 and $20 \%$ of the DOC, respectively, in the No Addition tank, and as much as 38 and $33 \%$ in the algal mesocosms. In all mesocosms, the fraction of DOC that was TCHO and amino acids increased throughout the experiment and their fractional contributions to total DOC were closely related to each other $\left(\mathrm{r}^{2}=0.75, \mathrm{n}=10\right)$, indicating the same source of biomolecules. The increased fractions of carbohydrates and amino acids may point to an indirect effect due to phytoplankton production since total DOC declined.

The results from the mesocosm experiments mirror observations made on marine DOM. Previous findings from oceanic surface waters showed that dissolved carbohydrates account for 20 to $30 \%$ of the dissolved material (Benner et al. 1992, Pakulski \& Benner 1994), whereas dissolved proteins are in general much lower $(<10 \%)$. In ultra-filtered dissolved organic matter (UDOM), McCarthy et al. (1996) found that dissolved carbohydrates and amino acids together comprised up to $23-33 \%$ of DOC and that carbohydrates were more refractory compared to proteins. However, in mesotrophic Lake Constance, both dissolved neutral carbohydrates and proteins accounted for 47 to $100 \%$ of the 
labile DOC pool, which was preferentially degraded by heterotrophic bacteria (Weiss \& Simon 1999). In our study, glucose was the most prominent DFCHO (Fig. 9) to be taken up efficiently by bacteria (Weiss \& Simon 1999). The mol\% composition of DCCHO, however, differed between mesocosms and often was variable in time. Glucose in the polymeric DCCHO fraction of the Phaeocystis tank, for example, was reduced during the breakdown of the algae on Days 16 and 18, and was lowest during the early stage of the diatom bloom. In both algal mesocosms, the mol\% of glucose in the DCCHO fraction significantly increased towards the end of the experiment, presumably as a result of increased algal release.

\section{Dissolved carbohydrates}

The concentration and composition of dissolved carbohydrates in this experiment were controlled by the activities of both phytoplankton and bacteria, and also varied with the type of phytoplankton present in the system (Fig. 9). Neutral carbohydrates accounted for less than a third of total carbohydrates in the 3 mesocosms. This finding is consistent with those of Skoog \& Benner (1997), which show that neutral carbohydrates only comprise 1 to $4 \%$ of DOC and 10 to $20 \%$ of total carbohydrates. The results, however, contrast with those of Biersmith \& Benner (1998), who found that neutral carbohydrates accounted for a much greater fraction of total carbohydrates in the $>1 \mathrm{kDa}$ fraction of marine DOC and of fresh algal POC (53 and 54\%, respectively). Meon \& Kirchman (2001) demonstrated that neutral carbohydrates of phytoplankton origin can be divided into 2 pools: a large, labile fraction (ca. $90 \%$ ) and a smaller, more refractory one (ca. 10\%). A high degree of degradability has been shown for polysaccharides released from a Phaeocystis bloom (Janse et al. 1999) and by a culture of Thalassiosira weissflogii (Aluwihare \& Repeta 1999). A decreasing contribution of neutral carbohydrates to TCHO in parallel to an actual DCCHO removal can only be seen in the Phaeocystis tank, indicating a high microbial degradability. In the No Addition and the Diatom tanks, however, the decreasing fraction of DCCHO of TCHO was mainly due to a build up of TCHO and not due to removal of DCCHO. Neutral carbohydrates, thus, should not necessarily be treated as a homogenous group, as demonstrated by the fact that potential hydrolysis rates of 2 soluble glucose-containing polysaccharides (pullulan and laminarin) differed by more than an order of magnitude in our mesocosms (Murray et al. 2007).

Since concentrations of dissolved neutral carbohydrates were positively correlated with chl $a$ in the Diatom tank $\left(\mathrm{r}^{2}=0.72, \mathrm{p}<0.01, \mathrm{n}=10\right)$, we assume that production of DCCHO was tightly linked to diatom growth. This is in agreement with previous results (e.g. Biersmith \& Benner 1998, Meon \& Kirchman 2001) that showed an increased release of DCCHO during the development of various algal blooms. Concentrations of TCHO increased during the growth of Phaeocystis and diatoms. In both algal mesocosms, however, TCHO also rapidly decreased towards the end of the experiment, indicating a delicate balance between production by algae and degradation by bacteria (e.g. Meon \& Kirchman 2001 and references therein). A calculation of hypothetical turnover times of the TCHO pool can be made by dividing TCHO concentration at each time point by the summed extracellular enzyme activities (see Murray et al. 2007). Such a calculation suggests that the theoretical turnover times of TCHO are quite rapid, varying from ca. 3 to $9 \mathrm{~d}$ through the course of the experiment. As with DOC concentrations and composition in general, it appears that also bacterial activities have modified the abundance and composition of dissolved carbohydrates in all 3 mesocosms.

\section{Dissolved amino acids}

The activities of heterotrophic bacteria also left their mark on the dissolved amino acid pool in all 3 mesocosms. Dissolved amino acids in all mesocosms constituted between 10 and $30 \%$ of DOC (Fig. 8), with a definite contribution to accumulation from the microbial population, and possibly from large phytoplankton as well. A previous mesocosm experiment observed the accumulation of refractory, bloom-derived DCAA pushing their contribution to the DOC pool up to the similarly high level of $19 \%$ by the end of the experiment (Meon \& Kirchman 2001). The refractory nature of the DCAA pool in our experiment is indicated by increased concentrations of the non-protein amino acid $\beta$-alanine (from initially $<3$ to $>8 \%$ ) and the relatively constant mol\% composition of DCAA in all mesocosms.

Accumulation of DFAA in the Phaeocystis tank was highest, especially during the breakdown of the algal cells due to high flagellate grazing, suggesting hydrolysis of proteins and subsequent release of DFAA into the surrounding water (Smith et al. 1992, Rosenstock \& Simon 2001). Massive lysis of algal cells is indicated by a dramatic increase in mol\% of alanine, which comprised $>80 \%$ of all DFAA at the end of the experiment in the Phaeocsytis tank (Appendix 1, available as Supplementary Material online at www.int-res.com/ articles/suppl/a049p143_app.pdf) and its high proportion of total DOC in the same mesocosm (Fig. 9). In contrast, mol\% composition of DFAA in the Diatom tank was greatly dominated by the acidic amino acid 
glutamate (25 to $65 \mathrm{~mol} \%$ ), which even accounted for a substantial fraction of total DOC (Fig. 9). Except for the anomalous Day 14, however, there was no net increase of DFAA in the Diatom tank. This may indicate a relatively low release of DFAA by protein hydrolysis where flagellate grazing of the diatoms was insignificant. The simultaneous absence of a net increase, changes in quality, and the high contribution of DFAA to total DOC in this mesocosm may point to phytoplankton release and to modification by bacterial activity at the same time (Murray et al. 2007).

\section{Particulate amino acids}

Although gains in POC concentrations were greatest in the Diatom tank and lowest in the No Addition tank, the fractional contribution of PCAA to total POC was broadly similar in all 3 mesocosms and increased in a consistent manner across all 3 mesocosms (Fig. 8). In all 3 mesocosms, PCAA accounted for only 5 to $10 \%$ of POC, a level that is significantly lower than that of sediment trap materials (17 to $38 \%$ ), but similar to those in sediments (3 to $14 \%$; Cowie \& Hedges 1992). Since our particles, especially in the algal mesocosms, were primarily composed of fresh phytoplankton, there is a chance that our measurements underestimate the real protein content. It has been suggested that filtration of POM onto GF/F filters may result in a significant loss of PCAA (M. Lunau unpubl. data). High mol percentages of aspartate and glutamate have been also found in axenic algal cultures, implying that they are indicative of algal proteins (Brown 1991, Mannino \& Harvey 2000, Grossart et al. 2006). The significant increase in PCAA with phytoplankton and bacterial biomass and its rise in conjunction with that of POC suggest that our measurements are representative of total PCAA concentrations.

Exopolymer particles included in PCAA (e.g. CSP) can be also produced by heterotrophic bacteria (Stoderegger \& Herndl 1999). In our experiments, heterotrophic bacteria increased substantially in both algal mesocosms (Murray et al. 2007) and may have contributed not only to degradation but also to formation of CSP and similar particles, some of which can be highly resistant to further bacterial degradation (Søndergaard et al. 2000).

\section{CONCLUSIONS}

Concentration and composition of DOM in the mesocosms were controlled by both the activities of phytoplankton and bacteria. Our carbon budgets show that budgets of DFAA and especially of non-neutral carbo- hydrates ('other $\mathrm{DCHO}^{\prime}$ ) were positive in the 2 phytoplankton mesocosms, indicating that their dynamics were tightly linked to those of the phytoplankton. Only the Phaeocystis tank showed a negative budget for DCCHO, which may have been linked to its specific bacterial community composition (Murray et al. 2007). Changes in concentration and quality of dissolved carbohydrates in both algal mesocosms suggest a significant turnover of these materials by bacteria. DCAA showed a positive carbon budget for all mesocosms, indicating that DCAA production either by exoenzymatic hydrolysis or algal exudation surpassed bacterial consumption. Total dissolved carbohydrates and proteins comprised a substantial fraction of the DOC pool in all 3 mesocosms. Turnover of dissolved carbohydrates and proteins, however, could only partly explain that of total DOC, implying that other dissolved organic matter, e.g. fatty acids and other polymeric organic matter, were also important for overall $\mathrm{C}$ - and nutrient cycling.

Acknowledgements. We thank L. von Harbou, M. Schmidt, and S. Schlake for help with the sampling, and Prof. M. Simon from the ICBM of the University of Oldenburg for many stimulating discussions and for providing laboratory space and technical equipment. C. Carlson and 2 anonymous reviewers are thanked for all their stimulating comments on an earlier version of the manuscript.

\section{LITERATURE CITED}

Aluwihare LI, Repeta DJ (1999) A comparison of the chemical characteristics of oceanic DOM and extracellular DOM produced by marine algae. Mar Ecol Prog Ser 186: 105-117

Aluwihare LI, Repeta DJ, Chen RF (1997) A major biopolymeric component to dissolved organic carbon in surface sea water. Nature 387:166-169

Baines SB, Pace ML (1991) The production of dissolved organic matter by phytoplankton and its importance to bacteria: patterns across marine and freshwater systems. Limnol Oceanogr 36:1078-1090

Benner R, Pakulski JD, McCarthy M, Hedges JS, Hatcher PG (1992) Bulk chemical characteristics of dissolved organic matter in the ocean. Science 255:1561-1564

Biddanda B, Benner R (1997) Carbon, nitrogen, and carbohydrate fluxes during the production of particulate and dissolved organic matter by marine phytoplankton. Limnol Oceanogr 42:506-518

Biersmith A, Benner R (1998) Carbohydrates in phytoplankton and freshly produced dissolved organic matter. Mar Chem 63:131-144

Borch NH, Kirchman DL (1999) Protection of protein from bacterial degradation by submicron particles. Aquat Microb Ecol 16:265-272

Børsheim KY, Myklestad SM (1997) Dynamics of DOC in the Norwegian Sea inferred from monthly profiles collected during 3 years at $66^{\circ} \mathrm{N}, 2^{\circ}$ E. Deep-Sea Res I 44:593-601

Børsheim KY, Myklestad SM, Sneli JA (1999) Monthly profiles of DOC, mono- and polysaccharides at two locations in the Trondheimfjord (Norway) during two years. Mar Chem 63:255-272 
Brown RW (1991) The amino-acid and sugar composition of 16 species of microalgae used in mariculture. J Exp Mar Biol Ecol 145:79-99

Canuel EA, Zimmerman AR (1999) Composition of particulate organic matter in the southern Chesapeake Bay: sources and reactivity. Estuaries 22:980-994

Carlson CA, Ducklow HW, Hansell DA, Smith WO (1998) Organic carbon partitioning during spring phytoplankton blooms in the Ross Sea polynya and the Sargasso Sea. Limnol Oceanogr 43:375-386

Cowie GL, Hedges JI (1992) Sources and reactivities of amino acids in a coastal marine environment. Limnol Oceanogr 37:703-724

Engel A, Goldthwait S, Passow U, Alldredge AL (2002) Temporal decoupling of carbon and nitrogen dynamics in a mesocosm diatom bloom. Limnol Oceanogr 47:753-761

Engel A, Thoms S, Riebesell U, Rochelle-Newal E, Zondervan I (2004) Polysaccharide aggregation as a potential sink of marine dissolved organic carbon. Nature 428:929-932

Grossart HP, Simon M (1998) Significance of limnetic organic aggregates (lake snow) for the sinking flux of particulate organic matter in a large lake. Aquat Microb Ecol 15: 115-125

Grossart HP, Czub G, Simon M (2006) Specific interactions of planktonic algae and bacteria: implications for aggregation and organic matter cycling in the sea. Environ Microbiol 8:1074-1084

Janse I, Van Rijssel M, Ottema A, Gottschal JC (1999) Microbial breakdown of Phaeocystis mucopolysaccharides. Limnol Oceanogr 44:1447-1457

Lancelot C (1984) Extracellular release of small and large molecules by phytoplankton in the southern bight of the North Sea. Estuar Coast Shelf Res 18:65-77

Lancelot C (1995) The mucilage phenomenon in the continental coastal waters of the North Sea. Sci Total Environ 165: 83-102

Lancelot C, Billen G (1985) Carbon-nitrogen relationship in nutrient metabolism of a coastal-marine ecosystem. In: Jannasch HW, Williams PJleB (eds) Advances in aquatic microbiology, Vol 3. Academic Press, London, p 263-321

Laws EA (1991) Photosynthetic quotients, new production, net community production in the open ocean. Deep-Sea Res 38:143-167

Lindroth P, Mopper K (1979) High performance liquid chromatography determination of subpicomole amounts of amino acids by precolumn fluorescence derivatisation with OPA. Anal Chem 51:1667-1674

Mannino A, Harvey HR (2000) Biochemical composition of particles and dissolved organic matter along an estuarine gradient: sources and implications for DOM reactivity. Limnol Oceanogr 45:775-788

McCarthy M, Hedges J, Benner R (1996) Major biochemical composition of dissolved high molecular weight organic matter in seawater. Mar Chem 55:281-297

Meon B, Kirchman DL (2001) Dynamics and molecular composition of dissolved organic material during experimental phytoplankton blooms. Mar Chem 75:185-199

Mopper K, Schultz A, Chevolot L, German C, Revuelta R, Dawson R (1992) Determination of sugars in unconcentrated seawater and other natural waters by liquid chromatography and pulsed amperometric detection. Environ Sci Technol 26:133-138

Murray AE, Arnosti C, De La Rocha CL, Grossart HP, Passow

Editorial responsibility: Craig Carlson,

Santa Barbara, California, USA
U (2007) Microbial dynamics in autotrophic and heterotrophic seawater mesocosms. II. Bacterial community structure and hydrolytic enzyme activities. Aquat Microb Ecol 49:123-141

Myklestad SM (1974) Production of carbohydrates by marine planktonic diatoms. I. Comparison of nine different species in culture. J Exp Mar Biol Ecol 15:261-274

Myklestad SM (1995) Release of extracellular products by phytoplankton with special emphasis on polysaccharides. Sci Total Environ 165:155-164

Myklestad SM, Holm-Hansen O, Varum KM, Volcani B (1989) Rate of release of extracellular amino acids and carbohydrates from the marine diatom Chaetoceros affinis. J Plankton Res 11:763-773

Myklestad SM, Skanoy E, Hestmann S (1997) A sensitive and rapid method for analysis of dissolved mono- and polysaccharides in seawater. Mar Chem 56:279-286

Obernosterer I, Herndl GJ (1995) Phytoplankton extracellular release and bacterial growth: dependence on the inorganic N:P ratio. Mar Ecol Prog Ser 116:247-257

Pakulski JD, Benner R (1994) Abundance and distribution of carbohydrates in the ocean. Limnol Oceanogr 39:930-940

Passow U, De La Rocha CL, Arnosti C, Grossart HP, Murray AE, Engel A (2007) Microbial dynamics in autotrophic and heterotrophic seawater mesocosms. I. Effect of phytoplankton on the microbial loop. Aquat Microb Ecol 49:109-121

Rosenstock B, Simon M (2001) Sources and sinks of dissolved free amino acids and protein in a large and deep mesotrophic lake. Limnol Oceanogr 46:644-654

Skoog A, Benner R (1997) Aldoses in various size fractions of marine organic matter: implications for carbon cycling. Limnol Oceanogr 42:1803-1813

Smith DC, Simon M, Alldredge AL, Azam F (1992) Intense hydrolytic enzyme-activity on marine aggregates and implications for rapid particle dissolution. Nature 359(6391):139-142

Søndergaard M, Williams PJleB, Cauwet G, Riemann B, Robinson C, Terzic S, Woodward EMS, Worm J (2000) Net accumulation and flux of dissolved organic carbon and dissolved organic nitrogen in marine plankton communities. Limnol Oceanogr 45:1097-1111

Stoderegger KE, Herndl GJ (1999) Production of exopolymer particles by marine bacterioplankton under contrasting turbulence conditions. Mar Ecol Prog Ser 189:9-16

Thingstad TF, Lignell R (1997) Theoretical models for the control of bacterial growth rate, abundance, diversity and carbon demand. Aquat Microb Ecol 13:19-27

Thingstad TF, Hagström Å, Rassoulzadegan F (1997) Accumulation of degradable DOC in surface waters: Is it caused by a malfunctioning microbial loop? Limnol Oceanogr 42:398-404

Weiss M, Simon M (1999) Consumption of labile dissolved organic matter by limnetic bacterioplankton: the relative significance of amino acids and carbohydrates. Aquat Microb Ecol 17:1-12

Williams PJleB (1995) Evidence for the seasonal accumulation of carbon-rich dissolved organic material, its scale in comparison with changes in particulate material and the consequential effect on net $\mathrm{C} / \mathrm{N}$ assimilation ratios. Mar Chem 51:17-29

Williams PJleB (1998) The balance of plankton respiration and photosynthesis in the open ocean. Nature 394:55-57

Submitted: December 19, 2006; Accepted: August 27, 2007

Proofs received from author(s): October 30, 2007 